\title{
SISTEM POLITIK DEMOKRASI \\ DALAM BIAS HEGEMONI NEGARA: \\ Telaah Gagasan Politik Antonio Gramsci
}

\author{
Kurniati
}

Fakultas Syariah dan Hukum UIN Alauddin Makassar

\begin{abstract}
The system of democracy politic in state hegemony biased has inspired the political arguments of Antonio Gramsci. He has contributed to reorient the state hegemony inspired by Marxism by providing some innovations especially in the political frame in the effort. Hegemony and democracy must be adjusted politically to provide a democratical civil society that can be an active consensus so that they can participate actively where the state, by the use of its authority in hegemony, facilitates the society to rights distribution.
\end{abstract}

Keywords:

Democracy Politic, State Hegemony, Antonio Gramsci

\begin{abstract}
Abstrak
Sistem politik demokrasi dalam bias hegemoni negara telah mengilhami argumen politik Antonio Gramsci. Gramsci telah berkontribusi dalam pemikiran tentang reorientasi hegemoni negara yang diilhami oleh Marxisme dengan menambahkan pemikiran tentang kerangka politik. Hegemoni dan demokrasi harus disesuaikan secara politis untuk mewujudkan masyarakat sipil yang demokratis yang dapat menjadi konsensus aktif sehingga mereka dapat berpartisipasi secara aktif di mana negara, dengan menggunakan otoritasnya dalam hegemoni, memfasilitasi masyarakat dalam hal mengenai penyetaraan hak.
\end{abstract}

Kata Kunci:

Politik Demokrasi, Hegemoni Negara, Antonio Gramsci

\section{A. PENDAHULUAN}

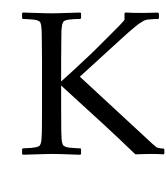

ebebasan merupakan hak yang imanen dengan keberadaan setiap individu sebagai seorang manusia. Tidak salah kemudian apabila tokoh sekelas Jean Paul Sartre pernah menyatakan bahwa "we are condemned to be free" meskipun kemudian pernyataan tersebut dianggap terlalu ekstrem yang seolah-olah menggambarkan kebebasan manusia tidak lagi terbatas. Kebebasan yang terikat oleh tata nilai yang saling bersinergi satu sama lain merupakan kebebasan yang dituju 
oleh demokrasi yang mendudukkan rakyat sebagai pemegang kekuasaaan tertinggi dalam menentukan arah kebijakan negara. Konsekuensinya, demokrasi meniscayakan bahwa kebebasan merupakan suatu partisipasi komunal dari rakyat sebagai sintesis dari berbagai partisipasi individu demi tercapainya kepentingan bersama untuk selanjutnya dapat dikatakan sebagai kepentingan komunal.

Dalam konsep civil society, demokrasi dalam kehidupan suatu bangsa merupakan prasyarat tercapainya kebebasan rakyat dalam pencapaian hak-hak politiknya. Menyikapi hal tersebut, Haedar Nashir mengemukakan bahwa demokrasi dalam posisinya sebagai sistem politik diyakini merupakan suatu alternatif atas berbagai kekurangan yang dimiliki sistem politik yang ada pada model pemerintahan berbagai bangsa seperti aristokrasi, timokrasi, oligarki, apalagi tirani. Demikian kuatnya paham demokrasi tersebut sehingga konsepnya telah menjadi keyakinan politik banyak bangsa-bangsa di dunia yang pada akhirnya bermetamorfosis menjadi -isme. ${ }^{1}$ Dalam kerangka praktisnya, proses demokrasi yang berlangsung belum menunjukkan hasil yang memuaskan. Denyut demokrasi lebih menampakkan diri dalam bentuk yang sifatnya formalitas yang belum menyerap ke dalam relung-relung kehidupan publik yang faktual. Kehidupan politik yang berkembang masih sarat dengan nuansa yang sifatnya kontra-produktif. Bahkan dalam derajat tertentu bertentangan dengan nilai-nilai demokrasi atau lebih tepatnya bertentangan dengan nilai-nilai moral. ${ }^{2}$

Saat negara mulai mengokohkan hegemoninya terhadap rakyat, semangat demokrasi sedang dipertaruhkan. Hegemoni negara atas rakyatnya pada dasarnya bukan hal yang tabu untuk selanjutnya dijustifikasi mereduksi nilai demokrasi tersebut. Tipologi demokrasi yang paradoks bisa menjadi pintu masuk dalam memahami fenomena ini seperti yang digambarkan oleh Saefullah Fatah yang menyatakan bahwa tipologi paradoks demokrasi tergambar pada satu sisi yang mensyaratkan adanya kebebasan untuk berkompetisi dan berkonflik dalam pencapaian tujuan tapi pada sisi lain mensyaratkan adanya keteraturan, kestabilan dan konsensus dalam penerapannya. ${ }^{3}$ Yang menjadi masalah kemudian adalah saat politik demokrasi dipolitisasi sedemikian rupa demi tercapainya kepentingan individu atau kelompok sebagai bagian dari kelas strata sosial atas kelas strata sosial yang lainnya. Demokrasi dalam konteks ini terbonsai oleh kepentingan sekelompok elite yang menguasai negara untuk mengokohkan hegemoninya yang bias atas nama negara.

Antonio Gramsci sebagai salah seorang tokoh yang hidup pada situasi dengan hegemoni negara yang kuat yang bersambut dengan bangkitnya fasisme reaksioner atas hegemoni tersebut telah mengajukan banyak gagasan politik cemerlang dalam

\footnotetext{
${ }^{1}$ Haedar Nashir, Pragmatisme Politik Kaum Elite, (Yogyakarta: Pustaka Pelajar, 1999), h. 37

2 Abd. A'la, Jahiliyah Kontemporer dan Hegemoni Nalar Kekerasan: Merajut Islam Indonesia, Membangun Peradaban Dunia, (Yogyakarta: LKiS, 2014), h. 34

${ }^{3}$ Saefullah Fatah, Masalah dan Prospek Demokrasi di Indonesia, (Jakarta: Ghalia Indonesia, 1994), h. 8
} 
kaitannya dengan sistem politik demokrasi dalam bias hegemoni negara yang sedikit banyak banyak terinspirasi pada pemikiran Karl Marx dan Lenin.

\section{B. PEMBAHASAN}

\section{Antonio Gramsci: Latar Belakang dan Corak Pemikirannya}

Antonio Gramsci merupakan seorang tokoh yang memiliki kontribusi besar dalam mengembangkan pemikiran Marxisme khususnya dalam lokus politik dan relevansinya dengan hegemoni negara. Ia lahir di Ales, Sardinia pada 22 Januari 1891. Pada tahun 1911, Antonio Gramsci memperoleh beasiswa untuk melanjutkan studi pada Universitas Turin dimana dalam proses tersebut ia banyak belajar pemikiran filosof idealis Beneddetto Croce yang selanjutnya juga banyak mempengaruhi gagasan-gagasannya kemudian. Perhatiannya yang besar terhadap gerakan sosial membuatnya terlibat pada berbagai organisasi sosial yang salah satunya adalah Partai Sosialis Italia pada tahun 1913 serta memimpin mingguan ternama di Turin yaitu Ordiene Nuovo pada tahun 1919. ${ }^{4}$ Sebagai seorang filosof idealis, Beneddetto Croce dikenal sebagai tokoh yang sangat menentang sistem pemerintahan yang fasis sehingga Antonio Gramsci yang banyak terpengaruh dengan gagasan-gagasan Beneddetto Croce menjadi tokoh sosialis yang menentang sistem pemerintahan yang fasis yang pada masa itu ditunjukkan oleh Mussolini.

Dalam perkembangannya, sikap anti fasisme yang ditunjukkan oleh Antonio Gramsci menuntunnya pada proses kritik ideologi yang panjang termasuk mendudukkan ideologi sosialisme sebagai ideologi yang merekonstruksi ideologi komunisme yang ramah terhadap demokrasi. Upaya ini mendapatkan momennya terutama saat ia sempat merantau ke Rusia dari tahun 1922 sampai 1924. Setelah kembali ke Italia, Antonio Gramsci terpilih sebagai anggota parlemen Italia sebaga wakil kaum sosialis dengan mengendarai partai komunis yang selanjutnya beretamorfosis menjadi partai yang sektarian pada kaum buruh dengan basis gerakan massanya. Pada tahun 1926, Antonio Gramsci dijatuhi hukuman penjara 20 tahun oleh pemerintahan fasis Mussolini. Pada 27 April 1937, ia meninggal dunia di penjara dengan meninggalkan banyak gagasan-gagasan melalui catatan hariannya. ${ }^{5}$ Hal ini mengisyaratkan bahwa sebagai seorang tokoh sosialis yang aktif, temboktembok penjara tidak membuat gagasan-gagasan cemerlangnya ikut terpenjara tapi justru dari balik penjara tersebut, Antonio Gramsci mengokohkan dirinya sebagai salah satu tokoh revolusioner yang pantas mendapatkan tempat dalam lembar sejarah perjuangan kaum proletar atas nama hak dasar manusia untuk terbebas dari penindasan dan ketidakadilan.

4 Mansour Fakih, "Gramsci di Indonesia," pengantar dalam Roger Simon, Gagasan-gagasan Politik Gramsci, (Yogyakarta: INSIST bekerjasama dengan Pustaka Pelajar, 2004), h. ix-x

5 Mansour Fakih, "Gramsci di Indonesia," pengantar dalam Roger Simon, Gagasan-gagasan Politik Gramsci, h. xii-xiii 
Beberapa karya dari Antonio Gramsci adalah 1) History, Phylosophy and Culture in the Young Gramsci, 1975, 2) Letters from Prison, 1973, 3) New Edinburgh Review: Three Special Gramsci Issues, 1974, 4) Selection from Cultural Writing, 1965, 5) The Modern Prince and Other Political Writing, 1957, 6) Selection from the Political Writings: 19101920, 1977, 7) Selection from the Political Writings: 1921-1926, 1978, serta 8) Selection from the Prison Notebooks, 1971. ${ }^{6}$ Berbagai karya tersebut telah menunjukkan perhatian Antonio Gramsci terhadap perjuangan kaum proletar yang tidak semestinya dipasung oleh hegemoni negara yang bias oleh kepentingan kaum borjuis termasuk ketidaksetujuannya terhadap sistem pemerintahan fasis yang mensyaratkan kepemimpinan dengan otoritas absolute yang jelas-jelas menciderai demokrasi.

\section{Demokrasi dan Hegemoni Negara}

Demokrasi secara etimologis terbangun atas dua kata dari bahasa Yunani yaitu "demos" yang berarti rakyat serta " cratein atau cratos" yang bermakna kekuasaan sehingga demokrasi dapat dipahami sebagai suatu keadaan negara dimana sistem pemerintahannya memberikan kedaulatan kepada rakyat. Adapun secara terminologi, demokrasi adalah suatu kondisi dimana rakyat memiliki kedaulatan dalam menilai kebijakan negara karena kebijakan tersebut pada akhirnya akan menentukan kehidupan rakyat itu sendiri. ${ }^{7}$

Dalam perkembangannya, demokrasi dianggap sebagai preferensi terbaik dalam relasi konstruktif antara negara dan masyarakat dengan tiga alasan yaitu, 1) demokrasi bukan saja menjadi bentuk ideal pemerintahan yang mungkin diciptakan tapi juga merupakan suatu doktrin politik luhur yang akan memberikan manfaat bagi kebanyakan negara, 2) demokrasi sebagai sistem politik dan pemerintahan mempunyai akar sejarah yang panjang sehingga telah teruji dapat menjamin terselenggaranya system politik yang stabil, 3) demokrasi merupakan system yang paling alamiah dan manusiawi sehingga semua rakyat di negara manapun memilih demokrasi apabila mereka diberikan kebebasan dalam menentukan pilihan. ${ }^{8}$

Negara adalah alat yang menjamin kedudukan kelas atas dengan perannya yang secara politik meredam usaha-usaha kelas bawah (proletar) untuk membebaskan diri dari kelas atas. Dalam konteks tersebut, negara dengan hegemoninya tidak mengabdi pada pemenuhan kebutuhan seluruh masyarakat tapi hanya melayani kepentingan kelas-kelas sosial tertentu. ${ }^{9}$ Hegemoni negara yang seperti ini telah dikritisi oleh Amin Rais dengan mengajukan antitesis bahwa negara harus menjadi wadah terlaksanakanya keadilan bagi semua masyarakatnya mulai dari keadilan hukum sampai pada keadilan sosial ekonomi. Keadilan yang sosial

${ }^{6}$ Nezar Patria dan Andi Arief, Antonio Gamsci, Negara \& Hegemoni, (Yogyakarta: Pustaka Pelajar, 2015), h. 55

7 Tim ICCE UIN Jakarta, Demokrasi, Hak Asasi Manusia dan Masyarakat Madani, (Jakarta: Kencana, 2005), h. 110-111

${ }^{8}$ Amin Rais, "Pengantar," dalam Demokrasi dan Proses Politik, (Jakarta: LP3ES, 1986), h. vii-viii

${ }^{9}$ Franz Magnis-Suseno, Filsafat sebagai Ilmu Kritis, (Yogyakarta: Kanisius, 1992), h. 
ekonomi tidak kalah pentingnya dari keadilan hukum karena tanpanya akan tercipta ketimpangan kelas dalam strata sosial. Hegemoni negara yang didasarkan pada prinsip persamaan kesempatan (equality of opportunity) rentang menjadi pilar kapitalisme-liberal mengingat kelompok kaya (borjuis) dan kelompok miskin (protelar) berangkat dari titik yang berbeda sehingga yang kaya semakin kaya karena memiliki modal yang banyak sementara yang miskin cenderung menjadi pelayan yang kaya karena hanya tenaga yang dimiliki. ${ }^{10}$

Apa yang digambarkan oleh Amin Rais tersebut menarik untuk dicermati mengingat hegemoni negara yang cenderung dibenturkan dengan demokrasi sebagai dua entitas yang tidak bisa dipertemukan satu sama lain. Dalam hal ini, negara harus mampu menjadi agen penguatan demokrasi dimana semua pihak yang bernaung di bawah institusional negara dapat terfasilitasi pada suatu relasi sosial yang demokratis. Prinsip persamaan kesempatan (equality of opportunity) yang rentang menjadi pilar kapitalisme-liberal perlu diinterpretasikan ulang dimana kelompok kelompok kaya (borjuis) dan kelompok miskin (protelar) yang berangkat dari titik yang berbeda difasilitasi oleh negara dengan hegemoninya untuk dapat berangkat pada titik yang sama. Upaya ini dapat dilakukan dengan dua cara yaitu mengurangi dominasi kelompok kaya (borjuis) atau memfasilitasi pemberdayaan kelompok miskin (protelar).

Tidak bisa dipungkiri bahwa demokrasi yang biasa dibenturkan dengan hegemoni negara merupakan suatu fase transisi menuju kedewasaan dalam memahami substansi dari demokrasi itu sendiri. Dalam fase transisi tersebut, berbagai tantangan tentunya muncul sebagai suatu konsekuensi dari sebuah perubahan. Menyikapi hal tersebut, Iding L. Hasan dalam Andi Faisal Bakti dkk. mengemukakan bahwa transisi menuju demokrasi yang berlangsung di negaranegara Amerika Latin dan Eropa Selatan menghadapi beberapa tantangan yaitu:

1. Ketidakpastian.Transisi menuju demokrasi belum mendapatkan kepastian tentang apakah perubahan yang terjadi adalah transisi dari pemerintahan otoriter ke demokratis. Dalam kerangka praktisnya, transisi menuju demokrasi kadang-kadang terjebak pada kekisruhan dan ketidakaturan yang kemudian kontra produktif memunculkan rezim yang lebih otoriter.

2. Kultur versus struktur. Demokrasi yang timbul di masa transisi kadang-kadang tidak didukung oleh kultur politik yang mendukung semangat liberalism konstitusional. Pada sisi lain, struktur yang seringkali diwarnai dengan rezim otoriter tentu saja akan mengambil posisi mengamankan zona nyamannya yang dianggap terusik dengan adanya transisi menuju demokrasi.

3. Konflik. Perubahan meniscayakan suatu konflik yang diwarnai dengan pertentangan antar berbagai komponen dalam masyarakat. Transisi menuju demokrasi sebagai suatu aras perubahan dari yang tadinya bersifat "menekan"

${ }^{10}$ Amin Rais, Cakrawala Islam: Antara Cita dan Fakta, (Bandung: Mizan, 1992), h. 44-46 
menuju pada yang sifatnya "membebaskan" cenderung memunculkan konflik antara yang mendukung penekanan ataupun pembebasan. ${ }^{11}$

Berkaca pada berbagai tantangan transisi menuju demokrasi di atas, tergambar bahwa relasi demokrasi dan hegemoni negara terus mengalami perkembangan seiring dengan dinamika menuju transisi demokrasi tersebut yang disertai dengan kesiapan struktur negara yang akomodatif sistem pemerintahan yang demokratis. Saat negara dengan hegemoninya memposisikan diri sebagai pilar pengembangan sistem pemerintahan yang demokratis, keduanya adalah sintesis yang saling menguatkan satu sama lain. Saat hegemoni tersebut alergi terhadap demokrasi dan lebih memilih bertahan pada zona nyamannya yang rezim oligarki apalagi rezim tirani, keduanya menjadi antitesa yang mengambil posisi berhadap-hadapan satu sama lain (vis a vis)

\section{Gagasan Politik Antonio Gramsci tentang Sistem Politik Demokrasi dalam Bias Hegemoni Negara}

Sebagai seorang yang banyak terpengaruh dengan aliran marxisme, Antonio Gramsci banyak melakukan kritik terhadap politik demokrasi dalam bias hegemoni negara. Dalam kerangka historisnya, hegemoni sebagai sebuah konsep politik telah digaungkan oleh sorang marxis Rusia yang bernama Plekanov tepatnya pada $1980 .{ }^{12}$ Dalam perkembangannya, konsep hegemoni yang digagas oleh Antonio Gramsci memberikan pengembangan atas apa yang digaungkan oleh Plekanov tersebut dengan berbasis pada pengalaman hidup dalam pemerintahan fasis Mussolini di Italia.

Apa yang dilakukan oleh Antonio Gramsci tersebut tidak terlepas dari fakta bahwa demi kepentingan borjuasi domestik, kadang-kadang negara dijadikan sebagai alat mereka untuk membatasi gerak borjuasi internasional sehingga hegemoni negara dimanfaatkan sedemikian rupa atas nama kelas sosial. Dalam tesis negara dependen tergambar adanya kelemahan dalam mempergunakan metode analisis Marxis dimana penggunaannya tidak lebih dari sebuah jargon tapi lepas dari esensi analisis Marxis yang berpijak di tingkat kelas. ${ }^{13}$

The one that can be called "civil society", that is, the ensemble of organisms commonly called "private", and that of "political society" or "the state". These two levels correspond on the one hand to the function of "hegemony" which the dominant group exercises the troughout society and the other hand to that of "direct domination" or command thai is exercised through the state and juridical government. ${ }^{14}$

11 Iding L. Hasan, "Hukum dan Demokratisasi di Indonesia" dalam Andi Faisal Bakti dkk., Literasi Politik dan Konsolidasi Demokrasi, (Jakarta: Churia Press, 2012), h. 32-33

12 Robert Bocock, Hegemony, (London: Tavistock Publication, 1986), h. 24

${ }^{13}$ Vedi R. Hadiz, Politik Pembebasan: Teori-Teori Negara Pasca Kolonial, (Yogyakarta: Pustaka Pelajar dan Insist Press, 1999), h. 40-41

${ }^{14}$ Antonio Gramsci, Selection from the Prison Notebooks, (New York: International Publishers, 1976), h. 12 
Apa yang digambarkan oleh Antonio Gramsci tersebut menunjukan bahwa konsep civil society yang imanen dengan pemenuhan hak-hak setiap warga negara dalam sistem pemerintahan demokratis tidak alergi terhadap hegemoni negara sebagai masyarakat politik atas masyarakat sipil selama hegemoni yang terbentuk adalah hegemoni yang mampu mendudukkan negara dengan kerangka yuridisnya untuk mengatur pemenuhan hak-hak setiap warga negara secara demokratis. Lebih lanjut,

Menurut Martin Carnoy, Antonio Gramsci telah memberikan kontribusi yang besar terhadap pemikiran Karl Marx dengan kemampuannya mentransformasikan gagasan-gagasan marxisme menjadi suatu embrio politik marxisme yang khas. Menurut Antonio Gramsci, politik bukan sekedar aktivitas otonom dalam konteks perkembangan sejarah kekuatan material tapi politik lebih dari pada itu yaitu sebagai pusat aktivitas manusia yang dengannya kesadaran tunggal bersentuhan dengan alam dunia dan kehidupan sosial dengan segala bentuknya. ${ }^{15}$ Yang menjadi masalah kemudian adalah saat politik demokrasi dipolitisir untuk kepentingan yang sifatnya hedonis-pragmatis sehingga jauh dari substansi demokrasi sebagai media pemenuhan hak-hak warga negara tanpa melihat perbedaan kelas. Dalam kerangka teologis-normatifnya, Islam sebagaimana agama samawi lainnya seperti Yahudi dan Kristen sangat menghargai persamaan derajat tanpa ada sikap membeda-bedakan manusia berdasarkan perbedaan jenis kelamin, status sosial, warna kulit, suku bangsa, sampai agama. Manusia memiliki kedudukan yang sama di hadapan Tuhan. ${ }^{16}$

Hegemoni yang negara yang menggiring politik demokrasi pada kehidupan yang tidak demokratis merupakan politisasi hegemoni negara yang sangat dikecam oleh Antonio Gramsci. Dalam konteks ini, ia tidak menyalahkan hegemoni negara tapi perlu ada penjabaran prinsip pemberdayaan dari hegemoni negara tersebut terhadap rakyatnya. Antonio Gramsci berpendapat bahwa negara denga struktur hegemoninya dapat dipahami sebagai kesatuan kompleks dari perpaduan antara teori dan praktek dimana kelas yang berkuasa tidak cuma memperkuat justifikasi atas dominasinya tapi juga mengatur dominasi tersebut untuk memenangkan suatu konsensus aktif dari yang diatur. ${ }^{17}$ Gagasan politik Antonio Gramsci ini mengisyaratkan bahwa hegemoni negara perlu diarahkan pada upaya memberikan kesadaran sosial bagi seluruh warga negara untuk terlibat aktif dalam pembangunan negara yang dilandasi oleh kesadaran bersama bahwa apa yang dilakukan tersebut merupakan kerangka aplikatif dari demokrasi dimana konsensus aktif lahir dari rakyat, dilakukan oleh rakyat untuk selanjutnya kembali pada rakyat.

\footnotetext{
${ }^{15}$ Martin Carnoy, The State and Political Theory, (New Jersey: Princeton University Press, 1984), h. 65

16 William Ebenstein, "Democracy" dalam William D. Halsey dan Bernard Johnson (Eds), Collier Encyclopedia, (New York: Macmillan Education Company, 1988), h. 77

${ }^{17}$ Antonio Gramsci, Selection from the Prison Notebooks, (New York, International Publisher, 1976), h. 


\section{PENUTUP}

Antonio Gramsci telah memberikan kontribusi yang besar terhadap politik demokrasi dalam bias hegemoni negara. Hegemoni negara sebagai kerangka politik pemerintahan yang memiliki otoritas dalam mengendalikan distribusi pemenuhan hak-hak warga negaranya. Secara politis, hegemoni negara tersebut perlu didudukkan secara demokratis dengan mendudukkan rakyat sebagai bagian dari konsensus aktif untuk menentukan arah distribusi otoritas negara tersebut.

\section{Daftar Pustaka}

Abd. A'la, Jahiliyah Kontemporer dan Hegemoni Nalar Kekerasan: Merajut Islam Indonesia, Membangun Peradaban Dunia, Yogyakarta: LKiS, 2014.

Amin Rais, "Pengantar," dalam Demokrasi dan Proses Politik, Jakarta: LP3ES, 1986.

Amin Rais, Cakrawala Islam: Antara Cita dan Fakta, Bandung: Mizan, 1992.

Antonio Gramsci, Selection from the Prison Notebooks, New York, International Publisher, 1976.

Franz Magnis-Suseno, Filsafat sebagai Ilmu Kritis, Yogyakarta: Kanisius, 1992 Haedar Nashir, Pragmatisme Politik Kaum Elite, Yogyakarta: Pustaka Pelajar, 1999.

Iding L. Hasan, "Hukum dan Demokratisasi di Indonesia" dalam Andi Faisal Bakti dkk., Literasi Politik dan Konsolidasi Demokrasi, Jakarta: Churia Press, 2012.

Mansour Fakih, "Gramsci di Indonesia," pengantar dalam Roger Simon, Gagasangagasan Politik Gramsci, (Yogyakarta: INSIST bekerjasama dengan Pustaka Pelajar, 2004), h. ix-x

Martin Carnoy, The State and Political Theory, New Jersey: Princeton University Press, 1984.

Nezar Patria dan Andi Arief, Antonio Gamsci, Negara \& Hegemoni, Yogyakarta: Pustaka Pelajar, 2015.

Robert Bocock, Hegemony, London: Tavistock Publication, 1986.

Saefullah Fatah, Masalah dan Prospek Demokrasi di Indonesia, Jakarta: Ghalia Indonesia, 1994.

Tim ICCE UIN Jakarta, Demokrasi, Hak Asasi Manusia dan Masyarakat Madani, Jakarta: Kencana, 2005.

Vedi R. Hadiz, Politik Pembebasan: Teori-Teori Negara Pasca Kolonial, Yogyakarta: Pustaka Pelajar dan Insist Press, 1999.

William Ebenstein, "Democracy" dalam William D. Halsey dan Bernard Johnson (Eds), Collier Encyclopedia, New York: Macmillan Education Company, 1988. 